\title{
PEMBUATAN KUE KAPIT SARI DAUN LIDAH BUAYA ( Aloe vera L. ) SEBAGAI PRODUK ALAMIAH INOVATIF SIAP KONSUMSI BAGI MASYARAKAT NON AGRARIS UNTUK MENJAGA KESEHATAN LAMBUNG
}

\author{
Monalisa Fadhilah Haque ${ }^{1}$, Risa Kota Putra ${ }^{2 *}$, Dewi Ratnasari ${ }^{3}$ \\ 1,2,3 Sekolah Tinggi Ilmu Kesehatan Holistik
}

*Korespondensi: Jl. Veteran No. 272 Ciseureuh Purwakarta, Email: dewiratnasari@stikesholistic.ac.id

\begin{abstract}
ABSTRAK
Latar Belakang: Lidah Buaya (Aloe vera L.) merupakan tanaman yang biasa digunakan masyarakat untuk mengobati penyakit lambung, tetapi penggunaan lidah buaya dalam bentuk ekstrak kurang praktis, mudah rusak dan akseptabilitasnya rendah. Sehingga perlu adanya inovasi sediaan yang praktis dan tahan lama pada penyimpanannya.

Tujuan: Penelitian ini bertujuan menyediakan produk alamiah inovatif dalam bentuk kue kapit sari daun lidah buaya (Aloe vera L.) untuk menjaga kesehatan lambung agar mudah dikonsumsi, praktis dan mudah dibawa kemana-mana oleh masyarakat non agraris.

Metode: Penelitian ini dilakukan dengan metode penelitian tindakan. Penelitian ini dibuat dengan mencampurkan 150 gram sari lidah buaya (Aloe vera L.), tepung beras 150 gr, tepung sagu $50 \mathrm{gr}$, satu butir telur ayam ras, 100 gr gula pasir, 0,3 gr garam dan tiga variasi jumlah santan kelapa yang berbeda. Variasi jumlah komposisi santan kelapa yang digunakan $30 \mathrm{~mL}, 80 \mathrm{~mL}$, dan $130 \mathrm{~mL}$.

Hasil: Hasil variasi komposisi yang paling memenuhi syarat kriteria kue kapit dan tingkat kerapuhan yang sedang yaitu dengan penambahan santan kelapa $80 \mathrm{~mL}$ dari jumlah adonan 400 $\mathrm{mL}$. Pengujian organoleptik sediaan dilakukan selama 21 hari pada suhu $25^{\circ} \mathrm{C}$ meliputi bau, bentuk, rasa, tektur, warna dan pertumbuhan jamur, hasil uji organoleptik sediaan kue kapit sari daun lidah buaya (Aloe vera L.) relatif stabil tidak terjadi perubahan dan tidak adanya pertumbuhan jamur selama 21 hari.

Simpulan: Simpulan dari penelitian ini didapatkan kriteria yang paling baik adalah F2 dengan penambahan santan kelapa $80 \mathrm{~mL}$ dari jumlah bahan $400 \mathrm{~mL}$ menunjukkan kandungan sari lidah buaya 9,37 gram yang dapat bertahan selama tiga minggu.
\end{abstract}

Kata kunci: Kue Kapit, Produk alamiah inovatif, Sari Daun Lidah Buaya (Aloe vera L)

\begin{abstract}
Background: Aloe vera (Aloe vera L.) is a plant that is commonly used by the community to treat gastric ailments, but the use of aloe vera in the form of extract is less practical, easily damaged and low acceptability. So there is a need for innovative, practical and durable preparations for storage. Objective: This study aims to provide innovative natural products in the form of aloe vera L. (Aloe vera L.) leaf juice to maintain healthy stomach so that it is easy to consume, practical and easy to carry everywhere by non-agricultural communities.

Methods: This research was conducted by the action research method. This research was made by mixing 150 grams of Aloe vera juice (Aloe vera L.), 150 gr rice flour, 50 gr sago flour, one egg, 100 gr sugar, $0.3 \mathrm{gr}$ salt and three variations of the amount of coconut milk that different. Variations in the composition of coconut milk used are $30 \mathrm{~mL}, 80 \mathrm{~mL}$, and $130 \mathrm{~mL}$.

Result: The composition variation results that most meet the criteria of capitite cake criteria and the level of fragility that is with the addition of $80 \mathrm{~mL}$ coconut milk from the amount of $400 \mathrm{~mL}$ batter. Organoleptic testing of preparations carried out for 21 days at a temperature of $25^{\circ} \mathrm{C}$ includes odor, shape, taste, texture, color and growth of mushrooms, the results of organoleptic testing of aloe vera leaf capitale leaf cake capitals (Aloe vera L.) are relatively stable, no changes and no mold growth for 21 days.

Conclusion: The conclusion from this study found that the best criterion is F2 with the addition of $80 \mathrm{~mL}$ coconut milk from the amount of $400 \mathrm{~mL}$ material showing the content of 9.37 grams of aloe vera which can last for three weeks.

Keywords: Kapit Cakes, Innovative natural products, Aloe vera leaf extract (Aloe vera L)
\end{abstract}




\section{PENDAHULUAN}

Setiap hari jutaan orang menderita Masyarakat non agraris lekat dengan rutinitas sibuk bekerja untuk memenuhi kebutuhan hidupnya. Hal ini akan mengakibatkan masyarakat non agraris cenderung memiliki potensial pola makan tidak sehat seperti halnya mengkonsumsi makanan pedas, asam-asaman, makanan siap saji, minum-minuman bersoda, melewatkan waktu makan karena sibuk, dan frekuensi makan yang sedikit yang dilakukan oleh masyarakat non agraris. Hal ini menjadi pemicu terjadinya gangguan dan penyakit pada pencernaan khususnya tukak lambung[1]. Masih banyak masyarakat yang belum mengetahui kegunaan tumbuhan yang bisa digunakan untuk mengobati penyakit pencernaan, khususnya tukak lambung. Tanaman obat yang berpotensi mengobati tukak lambung salah satunya adalah Lidah buaya[2].

Lidah buaya (Aloe vera L.) memiliki aktivitas anti ulkus karena mengandung glukomannan dan giberelin [3]. Aloe vera memberikan hasil kesembuhan ulkus yang hampir sama bila dibandingkan dengan sukralfat yang bersifat sitoprotektif dengan melindungi mukosa. ${ }^{[4]}$ Lidah buaya (Aloe vera) memiliki kemampuan meningkatkan faktor pertahanan lambung seperti peningkatan aktivitas superoxide dismutase (SOD) ${ }^{[5]}$.

Selama ini, masyarakat mengobati tukak lambung hanya dengan obat sintetis karena penggunaan yang praktis padahal kenyataannya pemakaian rutin obat sintetis dapat menyebakan efek samping timbulnya penyakit baru[6]. Namun penggunaan lidah buaya secara tradisional memerlukan bahan yang selalu tersedia dan tidak dapat disimpan lama sehingga perlu adanya inovasi sediaan yang praktis dan tahan lama dalam penyimpanannya.

Peneliti tertarik melakukan penelitian pembuatan makanan ringan kue kapit dari sari daun lidah buaya, yang akan memudahkan masyarakat mengkonsumsi sari daun lidah buaya menjadi makanan ringan yang praktis, tahan lama dalam penyimpanan dan mudah dibawa kemana-mana, sementara makanan ringan yang sudah dibuat pada penelitian sebelumnya adalah simping dari daun beluntas untuk perawatan kesehatan[7].

\section{METODE PENELITIAN}

Pada penelitian digunakan metode penelitian tindakan, Penelitian tindakan mengacu pada proses yang bergantian secara terus menerus antara penyelidikan dan tindakan antara praktik dan berpikir inovatifl[8]. Alat yang dibutuhkan dalam pembuatan kue kapit sari daun lidah buaya adalah baskom, pisau, saringan, timbangan, gelas ukur $25 \mathrm{~mL}$, gelas ukur $100 \mathrm{~mL}$, gelas ukur $500 \mathrm{~mL}$, cetakan kue semprong, pengaduk manual, kompor gas, gas elpiji, lap kain. Bahan yang digunakan pada penelitian ini diantaranya: Tepung beras $150 \mathrm{gr}$, Tepung sagu $50 \mathrm{gr}$, satu butir Telur ras, Gula pasir 100 gram, Garam 0,3 gram, lidah buaya 150 gram, dan santan kelapa $30 \mathrm{~mL}, 80 \mathrm{~mL}$, dan $130 \mathrm{~mL}$.

\subsection{Prosedur Pembuatan Sari Daun Lidah Buaya}

Langkah - langkah pembuatan sari daun lidah buaya adalah sebagai berikut: Siapkan daun Lidah buaya, cuci bersih dengan air mengalir, potong daun lidah buaya lalu mengambil bagian yang bening, Daging lidah buaya yang berbentuk gel 
direndam dalam larutan garam $0.1 \%$ sampai lendirnya keluar kemudian cuci dengan air bersih sebanyak 2 (dua) kali, Daging daun lidah buaya ditimbang sesuai kebutuhan kemudian diblender sampai hancur[9].

\subsection{Prosedur Pembuatan Kue Kapit Sari Daun Lidah Buaya}

Siapkan alat dan bahan, untuk 3 komposisi F1. F2, dan F3, masukkan telur dan gula pasir kedalam baskom, kemudian kocok menggunakan pengaduk manual sampai homogen dan mengembang, tambahkan tepung beras dan tepung sagu, sambil diaduk tambahkan sedikit garam dan sari daun lidah buaya (Aloe vera L.) diaduk hingga homogen, tambahkan santan kelapa sesuaikan perbandingan F1, F2, F3, kemudian aduk semua bahan sampai homogen, tampilan adonan kue kapit jangan terlalu encer ataupun terlalu kental, masukkan adonan ke dalam gelas ukur sampai $25 \mathrm{~mL}$ kemudian tuangkan kedalan cetakan kue kapit yang telah diolesi minyak kelapa, kemudian tutup cetakan, panaskan dengan api kecil selama 2-3 menit, selama pemanasan cetakan dibolak- balik supaya matang merata, kemudian buka tutup cetakan, ambil hasil cetakan kue kemudian selagi panas lipat kue kapit menggunakan lap kain yang bersih, lakukan ulang pengerjaan pencetakan kue kapit sampai adonan kue kapit habis, untuk komposisi F1, F2, dan F3, kemudian tiriskan kue kapit sari daun lidah buaya, kemas rapih dalam wadah tertutup. Beri etiket dan penandaan.

\section{HASIL PENELITIAN \& PEMBAHASAN}

Dosis sari daun lidah buaya (Aloe vera. $\mathrm{L}$ ) adalah $2 \times 75 \mathrm{gr} /$ hari [2]. Berikut hasil dan dosis/ kandungan kue kapit sari lidah buaya pada Tabel.3.1

Tabel. 3.1 Hasil jumlah kue kapit dan kandungan Sari Daun Lidah Buaya (Aloe vera. $\mathrm{L}$ )

\begin{tabular}{|c|c|c|c|}
\hline \multirow{2}{*}{ Bahan } & \multicolumn{3}{|c|}{ Variasi komposisi } \\
\hline & F1 & $F 2$ & F3 \\
\hline Sari lidah buaya & 150 gram & 150 gram & 150 gram \\
\hline Santan kelapa & $30 \mathrm{~mL}$ & $80 \mathrm{~mL}$ & $130 \mathrm{~mL}$ \\
\hline Jumlah bahan & $350 \mathrm{~mL}$ & $400 \mathrm{~mL}$ & $450 \mathrm{~mL}$ \\
\hline $\begin{array}{l}\text { Jumlah kue kapit yang } \\
\text { didapatkan per } 25 \mathrm{~mL}\end{array}$ & $\begin{array}{l}14 \text { kue kapit sari } \\
\text { daun lidah buaya. }\end{array}$ & $\begin{array}{l}16 \text { kue kapit sari } \\
\text { daun lidah buaya. }\end{array}$ & $\begin{array}{l}18 \text { kue kapit sari } \\
\text { daun lidah buaya. }\end{array}$ \\
\hline $\begin{array}{c}\text { Kandungan sari lidah } \\
\text { buaya per } 25 \mathrm{~mL} / \mathrm{satu} \\
\text { kue kapit }\end{array}$ & $10,71 \mathrm{gr}$ & $9,37 \mathrm{gr}$ & $8,33 \mathrm{gr}$ \\
\hline $\begin{array}{c}\text { Konsusmsi Kue Kapit/ } \\
\text { Hari }\end{array}$ & $\begin{array}{c}\text { Dosis } 1 \text { kali } \\
\text { konsumsi: } \\
7 \text { Kue. } \\
\text { Dosis } 1 \text { hari } \\
\text { konsumsi: } \\
2 x 7 \text { kue }=14 \text { kue } \\
\text { kapit. }\end{array}$ & $\begin{array}{c}\text { Dosis } 1 \mathrm{kali} \\
\text { konsumsi: } \\
8 \text { Kue. } \\
\text { Dosis } 1 \text { hari } \\
\text { konsumsi: } \\
2 x 8 \text { kue }=16 \text { kue } \\
\text { kapit. }\end{array}$ & $\begin{array}{l}\text { Dosis } 1 \mathrm{kali} \\
\text { konsumsi: } \\
9 \text { Kue. } \\
\text { Dosis } 1 \text { hari } \\
\text { konsumsi: } \\
2 \times 9 \text { kue }=18 \text { kue } \\
\text { kapit. }\end{array}$ \\
\hline
\end{tabular}


Pada Tabel.3.1 menunjukkan Hasil kue kapit sari daun lidah buaya yang didapat pada ketiga variasi komposisi yaitu pada F1 adalah 14 kue yang dihasilkan dari jumlah bahan kue kapit $350 \mathrm{~mL}$ dan satu kue kapit F1 memiliki kandungan lidah buaya sebanyak 10, 71 gram sehingga cara mengkonsumsi sebanyak 7 (tujuh ) kue kapit dua kali sehari, F2 didapatkan 16 kue kapit sari daun lidah buaya yang dihasilkan dari jumlah bahan kue kapit $400 \mathrm{~mL}$ dan satu kue kapit F2 memiliki kandungan lidah buaya sebanyak 9,37 gram sehingga cara mengkonsumsinya dianjurkan 8 (delapan) kue kapit 2 dua kali sehari, dan F3 didapatkan 18 kue kapit sari daun lidah buaya (Aloe vera L.) dan pada satu kue kapit F3 memiliki kandungan lidah buaya sebanyak 8,33 gram sehingga cara mengkonsumsinya adalah 9 kue dua kali sehari. Karakteristik awal kue kapit sari lidah buaya yang dibuat dengan tiga variasi komposisi pada Tabel.3.2

Tabel. 2 Hasil Kue kapit Sari Daun Lidah Buaya (Aloe vera)

\begin{tabular}{|c|c|c|c|c|c|c|}
\hline \multirow{2}{*}{ Formula } & \multicolumn{7}{|c|}{ Hasil kue kapit sari daun lidah buaya } \\
\cline { 2 - 7 } & Bau & Bentuk & Rasa & Tekstur & Warna & $\begin{array}{c}\text { Berat } \\
\text { Rata-rata } \\
\text { kue kapit }\end{array}$ \\
\hline \multirow{2}{*}{ F1 } & $\begin{array}{c}\text { Aroma } \\
\text { khas } \\
\text { telur. }\end{array}$ & $\begin{array}{c}\text { Berbentuk } \\
\text { seperti kipas, } \\
\text { utuh, tidak } \\
\text { pecah-pecah. }\end{array}$ & $\begin{array}{c}\text { Gurih dan } \\
\text { manis } \\
\text { seimbang. }\end{array}$ & $\begin{array}{c}\text { Renyah dan } \\
\text { tidak } \\
\text { mudah } \\
\text { rapuh. }\end{array}$ & $\begin{array}{c}\text { Coklat } \\
\text { kekuningan. }\end{array}$ & 13 gram \\
& $\begin{array}{c}\text { Aroma } \\
\text { khas } \\
\text { telur. }\end{array}$ & $\begin{array}{c}\text { Berbentuk } \\
\text { seperti kipas, } \\
\text { utuh, tidak } \\
\text { pecah-pecah. }\end{array}$ & $\begin{array}{c}\text { Gurih dan } \\
\text { manis } \\
\text { seimbang. }\end{array}$ & $\begin{array}{c}\text { Renyah dan } \\
\text { agak } \\
\text { mudah } \\
\text { rapuh. }\end{array}$ & $\begin{array}{c}\text { Coklat } \\
\text { kekuningan }\end{array}$ & 12 gram \\
\hline \multirow{2}{*}{ F3 } & $\begin{array}{c}\text { Aroma } \\
\text { khas } \\
\text { telur. }\end{array}$ & $\begin{array}{c}\text { Berbentuk } \\
\text { seperti kipas, } \\
\text { utuh, tidak } \\
\text { pecah-pecah. }\end{array}$ & $\begin{array}{c}\text { Gurih dan } \\
\text { manis } \\
\text { seimbang. }\end{array}$ & $\begin{array}{c}\text { Renyah dan } \\
\text { mudah } \\
\text { rapuh. }\end{array}$ & $\begin{array}{c}\text { Coklat } \\
\text { kekuningan }\end{array}$ & 11 gram \\
\hline
\end{tabular}

Pada Tabel 3.2 menunjukan hasil pada sediaan kue kapit sari daun lidah buaya dengan variasi komposisi F1, F2 dan F3 mempunyai hasil yang relatif sama pada bau, bentuk, rasa dan warna, tetapi berbeda dengan tekstur pada F1 menunjukkan tekstur renyah tidak mudah rapuh, F2 menunjukkan tekstur renyah dan agak mudah rapuh dan F3 menunjukkan tekstur renyah dan mudah rapuh, dan mempunyai berat rata- rata yaitu 13 gram (F1), 12 gram (F2) dan 11 gram (F3).

\subsection{Uji Organoleptik}

Kue kapit sari daun lidah buaya (Aloe vera L.) telah selesai dibuat kemudian dilakukan pengujian organoleptik dengan mengamati bentuk, bau, warna, rasa, tekstur dan jamur selama 3 (tiga) minggu setiap tiga hari sekali. Pada pengamatan ini yaitu menggunakan 15 sampel penelitian pada 
setiap variasi volume komposisi F1, F2 dan F3 pada suhu $25^{\circ} \mathrm{C}$.

Pengamatan dilakukan dimulai pada hari Kamis, 04 Juli 2019 - Kamis, 25 Juli 2019. Sediaan kue kapit pada Tabel. 3.3, Tabel. 3.4 dan Tabel. 3.5 menunjukkan hasil pengamatan yang relatif stabil selama tiga minggu berturut-turut, hasil pengujian organoleptik pada ketiga variasi relatif sama pada bau, bentuk, rasa dan warna, tetapi berbeda dengan tekstur pada F1 menunjukkan tekstur renyah tidak mudah rapuh, F2 menunjukkan tekstur renyah dan agak mudah rapuh dan F3 menunjukkan tekstur renyah dan mudah rapuh. Pengujian kerapuhan pada kue kapit yaitu dengan cara diuji/ dipatahkan dan hasil uji organoleptik kue kapit sari daun lidah buaya selama tiga minggu berturut-turut tidak ada tumbuhnya jamur.

Tabel 3.3 Hasil Pengamatan Kue Kapit Sari Lidah Buaya F1

\begin{tabular}{|c|c|c|c|c|c|c|c|c|c|c|}
\hline \multirow[b]{2}{*}{$\begin{array}{c}\text { SAMP } \\
\text { EL }\end{array}$} & \multirow{2}{*}{$\begin{array}{c}\text { Uji } \\
\text { Organ } \\
\text { olepti } \\
\text { k }\end{array}$} & \multicolumn{3}{|c|}{ Minggu Ke-1 } & \multicolumn{3}{|c|}{ Minggu ke-2 } & \multicolumn{3}{|c|}{ Minggu ke-3 } \\
\hline & & $\mathrm{H}+1$ & $\mathrm{H}+3$ & $\mathrm{H}+6$ & $\mathrm{H}+1$ & $\mathrm{H}+3$ & $\mathrm{H}+6$ & $\mathrm{H}+1$ & $\mathrm{H}+3$ & $\mathrm{H}+6$ \\
\hline \multirow{6}{*}{$\begin{array}{c}\text { F } 1 \\
( \\
\text { Lima } \\
\text { belas } \\
\text { Kue } \\
\text { Kapit } \\
\text { J }\end{array}$} & $\mathrm{Bau}$ & $\begin{array}{c}\text { Berarom } \\
\text { a khas } \\
\text { telur }\end{array}$ & $\begin{array}{c}\text { Berarom } \\
\text { a khas } \\
\text { telur }\end{array}$ & $\begin{array}{c}\text { Berarom } \\
\text { a khas } \\
\text { telur }\end{array}$ & $\begin{array}{c}\text { Berarom } \\
\text { a khas } \\
\text { telur }\end{array}$ & $\begin{array}{c}\text { Berarom } \\
\text { a khas } \\
\text { telur }\end{array}$ & $\begin{array}{l}\text { Berarom } \\
\text { a khas } \\
\text { telur }\end{array}$ & $\begin{array}{c}\text { Berarom } \\
\text { a khas } \\
\text { telur }\end{array}$ & $\begin{array}{c}\text { Berarom } \\
\text { a khas } \\
\text { telur }\end{array}$ & $\begin{array}{c}\text { Berarom } \\
\text { a khas } \\
\text { telur }\end{array}$ \\
\hline & $\begin{array}{c}\text { Bentu } \\
\mathrm{k}\end{array}$ & $\begin{array}{l}\text { berbentu } \\
\text { k seperti } \\
\text { kipas } \\
\text { utuh dan } \\
\text { tidak } \\
\text { pecah- } \\
\text { pecah }\end{array}$ & $\begin{array}{l}\text { berbentu } \\
\text { k seperti } \\
\text { kipas } \\
\text { utuh dan } \\
\text { tidak } \\
\text { pecah- } \\
\text { pecah }\end{array}$ & $\begin{array}{l}\text { berbentu } \\
\text { k seperti } \\
\text { kipas } \\
\text { utuh dan } \\
\text { tidak } \\
\text { pecah- } \\
\text { pecah }\end{array}$ & $\begin{array}{l}\text { berbentu } \\
\text { k seperti } \\
\text { kipas } \\
\text { utuh dan } \\
\text { tidak } \\
\text { pecah- } \\
\text { pecah }\end{array}$ & $\begin{array}{l}\text { berbentu } \\
\text { k seperti } \\
\text { kipas } \\
\text { utuh dan } \\
\text { tidak } \\
\text { pecah- } \\
\text { pecah }\end{array}$ & $\begin{array}{l}\text { berbentu } \\
\text { k seperti } \\
\text { kipas } \\
\text { utuh dan } \\
\text { tidak } \\
\text { pecah- } \\
\text { pecah }\end{array}$ & $\begin{array}{l}\text { berbentu } \\
\text { k seperti } \\
\text { kipas } \\
\text { utuh dan } \\
\text { tidak } \\
\text { pecah- } \\
\text { pecah }\end{array}$ & $\begin{array}{l}\text { berbentu } \\
\text { k seperti } \\
\text { kipas } \\
\text { utuh dan } \\
\text { tidak } \\
\text { pecah- } \\
\text { pecah }\end{array}$ & $\begin{array}{l}\text { berbentu } \\
\text { k seperti } \\
\text { kipas } \\
\text { utuh dan } \\
\text { tidak } \\
\text { pecah- } \\
\text { pecah }\end{array}$ \\
\hline & Jamur & Tidak ada & Tidak ada & Tidak ada & Tidak ada & Tidak ada & Tidak ada & Tidak ada & Tidak ada & Tidak ada \\
\hline & Rasa & $\begin{array}{c}\text { Gurih } \\
\text { manis } \\
\text { seimbang }\end{array}$ & $\begin{array}{c}\text { Gurih } \\
\text { manis } \\
\text { seimbang }\end{array}$ & $\begin{array}{c}\text { Gurih } \\
\text { manis } \\
\text { seimbang }\end{array}$ & $\begin{array}{c}\text { Gurih } \\
\text { manis } \\
\text { seimbang }\end{array}$ & $\begin{array}{c}\text { Gurih } \\
\text { manis } \\
\text { seimbang }\end{array}$ & $\begin{array}{c}\text { Gurih } \\
\text { manis } \\
\text { seimbang }\end{array}$ & $\begin{array}{c}\text { Gurih } \\
\text { manis } \\
\text { seimbang }\end{array}$ & $\begin{array}{c}\text { Gurih } \\
\text { manis } \\
\text { seimbang }\end{array}$ & $\begin{array}{c}\text { Gurih } \\
\text { manis } \\
\text { seimbang }\end{array}$ \\
\hline & $\begin{array}{c}\text { Tekst } \\
\text { ur }\end{array}$ & $\begin{array}{l}\text { Kering, } \\
\text { renyah, } \\
\text { tidak } \\
\text { mudah } \\
\text { rapuh }\end{array}$ & $\begin{array}{l}\text { Kering, } \\
\text { renyah, } \\
\text { tidak } \\
\text { mudah } \\
\text { rapuh }\end{array}$ & $\begin{array}{c}\text { Kering, } \\
\text { renyah, } \\
\text { tidak } \\
\text { mudah } \\
\text { rapuh }\end{array}$ & $\begin{array}{c}\text { Kering, } \\
\text { renyah, } \\
\text { tidak } \\
\text { mudah } \\
\text { rapuh }\end{array}$ & $\begin{array}{c}\text { Kering, } \\
\text { renyah, } \\
\text { tidak } \\
\text { mudah } \\
\text { rapuh }\end{array}$ & $\begin{array}{c}\text { Kering, } \\
\text { renyah, } \\
\text { tidak } \\
\text { mudah } \\
\text { rapuh }\end{array}$ & $\begin{array}{c}\text { Kering, } \\
\text { renyah, } \\
\text { tidak } \\
\text { mudah } \\
\text { rapuh }\end{array}$ & $\begin{array}{c}\text { Kering, } \\
\text { renyah, } \\
\text { tidak } \\
\text { mudah } \\
\text { rapuh }\end{array}$ & $\begin{array}{c}\text { Kering, } \\
\text { renyah, } \\
\text { tidak } \\
\text { mudah } \\
\text { rapuh }\end{array}$ \\
\hline & $\begin{array}{c}\text { Warn } \\
\text { a }\end{array}$ & $\begin{array}{c}\text { Coklat } \\
\text { kekuning } \\
\text { an. }\end{array}$ & $\begin{array}{c}\text { Coklat } \\
\text { kekuning } \\
\text { an. }\end{array}$ & $\begin{array}{c}\text { Coklat } \\
\text { kekuning } \\
\text { an. }\end{array}$ & $\begin{array}{c}\text { Coklat } \\
\text { kekuning } \\
\text { an. }\end{array}$ & $\begin{array}{c}\text { Coklat } \\
\text { kekuning } \\
\text { an. }\end{array}$ & $\begin{array}{c}\text { Coklat } \\
\text { kekuning } \\
\text { an. }\end{array}$ & $\begin{array}{c}\text { Coklat } \\
\text { kekuning } \\
\text { an. }\end{array}$ & $\begin{array}{c}\text { Coklat } \\
\text { kekuning } \\
\text { an. }\end{array}$ & $\begin{array}{c}\text { Coklat } \\
\text { kekuning } \\
\text { an. }\end{array}$ \\
\hline
\end{tabular}

Keterangan: F1 volume santan kelapa $30 \mathrm{~mL}$ dan volume akhir $350 \mathrm{~mL}$.

Tabel 3. 4 Hasil Pengamatan Kue Kapit Sari Lidah Buaya F2

\begin{tabular}{|c|c|c|c|c|c|c|c|c|c|c|}
\hline \multirow{2}{*}{$\begin{array}{c}\text { SAMP } \\
\text { EL }\end{array}$} & $\begin{array}{c}\text { Uji } \\
\text { Organ } \\
\text { olepti } \\
\mathrm{k}\end{array}$ & $\mathrm{H}+1$ & $\mathrm{H}+3$ & $\mathrm{H}+6$ & $\mathrm{H}+1$ & $\mathrm{H}+3$ & $\mathrm{H}+6$ & $\mathrm{H}+1$ & $\mathrm{H}+3$ & $\mathrm{H}+6$ \\
\hline & Bau & $\begin{array}{c}\text { Berarom } \\
\text { a khas } \\
\text { telur }\end{array}$ & $\begin{array}{c}\text { Berarom } \\
\text { a khas } \\
\text { telur }\end{array}$ & $\begin{array}{c}\text { Berarom } \\
\text { a khas } \\
\text { telur }\end{array}$ & $\begin{array}{c}\text { Berarom } \\
\text { a khas } \\
\text { telur }\end{array}$ & $\begin{array}{c}\text { Berarom } \\
\text { a khas } \\
\text { telur }\end{array}$ & $\begin{array}{c}\text { Berarom } \\
\text { a khas } \\
\text { telur }\end{array}$ & $\begin{array}{c}\text { Berarom } \\
\text { a khas } \\
\text { telur }\end{array}$ & $\begin{array}{c}\text { Berarom } \\
\text { a khas } \\
\text { telur }\end{array}$ & $\begin{array}{c}\text { Berarom } \\
\text { a khas } \\
\text { telur }\end{array}$ \\
\hline
\end{tabular}




\begin{tabular}{|c|c|c|c|c|c|c|c|c|c|c|}
\hline \multirow[t]{5}{*}{$\begin{array}{c}\text { ( } \\
\text { Lima } \\
\text { belas } \\
\text { kue } \\
\text { kapit } \\
\text { ) }\end{array}$} & $\begin{array}{c}\text { Bentu } \\
\mathrm{k}\end{array}$ & $\begin{array}{l}\text { berbentu } \\
\text { k seperti } \\
\text { kipas } \\
\text { utuh dan } \\
\text { tidak } \\
\text { pecah- } \\
\text { pecah }\end{array}$ & $\begin{array}{c}\text { berbentu } \\
\text { k seperti } \\
\text { kipas } \\
\text { utuh dan } \\
\text { tidak } \\
\text { pecah- } \\
\text { pecah }\end{array}$ & $\begin{array}{c}\text { berbentu } \\
\text { k seperti } \\
\text { kipas } \\
\text { utuh dan } \\
\text { tidak } \\
\text { pecah- } \\
\text { pecah } \\
\end{array}$ & $\begin{array}{c}\text { berbentu } \\
\text { k seperti } \\
\text { kipas } \\
\text { utuh dan } \\
\text { tidak } \\
\text { pecah- } \\
\text { pecah } \\
\end{array}$ & $\begin{array}{c}\text { berbentu } \\
\text { k seperti } \\
\text { kipas } \\
\text { utuh dan } \\
\text { tidak } \\
\text { pecah- } \\
\text { pecah } \\
\end{array}$ & $\begin{array}{c}\text { berbentu } \\
\text { k seperti } \\
\text { kipas } \\
\text { utuh dan } \\
\text { tidak } \\
\text { pecah- } \\
\text { pecah } \\
\end{array}$ & $\begin{array}{c}\text { berbentu } \\
\text { k seperti } \\
\text { kipas } \\
\text { utuh dan } \\
\text { tidak } \\
\text { pecah- } \\
\text { pecah } \\
\end{array}$ & $\begin{array}{c}\text { berbentu } \\
\text { k seperti } \\
\text { kipas } \\
\text { utuh dan } \\
\text { tidak } \\
\text { pecah- } \\
\text { pecah } \\
\end{array}$ & $\begin{array}{c}\text { berbentu } \\
\text { k seperti } \\
\text { kipas } \\
\text { utuh dan } \\
\text { tidak } \\
\text { pecah- } \\
\text { pecah } \\
\end{array}$ \\
\hline & Jamur & Tidak ada & Tidak ada & Tidak ada & Tidak ada & Tidak ada & Tidak ada & Tidak ada & Tidak ada & Tidak ada \\
\hline & Rasa & $\begin{array}{c}\text { Gurih } \\
\text { manis } \\
\text { seimbang }\end{array}$ & $\begin{array}{c}\text { Gurih } \\
\text { manis } \\
\text { seimbang }\end{array}$ & $\begin{array}{c}\text { Gurih } \\
\text { manis } \\
\text { seimbang }\end{array}$ & $\begin{array}{c}\text { Gurih } \\
\text { manis } \\
\text { seimbang }\end{array}$ & $\begin{array}{c}\text { Gurih } \\
\text { manis } \\
\text { seimbang }\end{array}$ & $\begin{array}{c}\text { Gurih } \\
\text { manis } \\
\text { seimbang }\end{array}$ & $\begin{array}{c}\text { Gurih } \\
\text { manis } \\
\text { seimbang }\end{array}$ & $\begin{array}{c}\text { Gurih } \\
\text { manis } \\
\text { seimbang }\end{array}$ & $\begin{array}{c}\text { Gurih } \\
\text { manis } \\
\text { seimbang }\end{array}$ \\
\hline & $\begin{array}{c}\text { Tekst } \\
\text { ur }\end{array}$ & $\begin{array}{c}\text { Kering, } \\
\text { renyah, } \\
\text { tidak } \\
\text { mudah } \\
\text { rapuh }\end{array}$ & $\begin{array}{c}\text { Kering, } \\
\text { renyah, } \\
\text { tidak } \\
\text { mudah } \\
\text { rapuh }\end{array}$ & $\begin{array}{c}\text { Kering, } \\
\text { renyah, } \\
\text { tidak } \\
\text { mudah } \\
\text { rapuh }\end{array}$ & $\begin{array}{c}\text { Kering, } \\
\text { renyah, } \\
\text { tidak } \\
\text { mudah } \\
\text { rapuh }\end{array}$ & $\begin{array}{c}\text { Kering, } \\
\text { renyah, } \\
\text { tidak } \\
\text { mudah } \\
\text { rapuh }\end{array}$ & $\begin{array}{c}\text { Kering, } \\
\text { renyah, } \\
\text { tidak } \\
\text { mudah } \\
\text { rapuh }\end{array}$ & $\begin{array}{c}\text { Kering, } \\
\text { renyah, } \\
\text { tidak } \\
\text { mudah } \\
\text { rapuh }\end{array}$ & $\begin{array}{c}\text { Kering, } \\
\text { renyah, } \\
\text { tidak } \\
\text { mudah } \\
\text { rapuh }\end{array}$ & $\begin{array}{c}\text { Kering, } \\
\text { renyah, } \\
\text { tidak } \\
\text { mudah } \\
\text { rapuh }\end{array}$ \\
\hline & $\begin{array}{c}\text { Warn } \\
\text { a }\end{array}$ & $\begin{array}{c}\text { Coklat } \\
\text { kekuning } \\
\text { an. }\end{array}$ & $\begin{array}{c}\text { Coklat } \\
\text { kekuning } \\
\text { an. }\end{array}$ & $\begin{array}{l}\text { Coklat } \\
\text { kekuning } \\
\text { an. }\end{array}$ & $\begin{array}{c}\text { Coklat } \\
\text { kekuning } \\
\text { an. }\end{array}$ & $\begin{array}{c}\text { Coklat } \\
\text { kekuning } \\
\text { an. }\end{array}$ & $\begin{array}{c}\text { Coklat } \\
\text { kekuning } \\
\text { an. }\end{array}$ & $\begin{array}{c}\text { Coklat } \\
\text { kekuning } \\
\text { an. }\end{array}$ & $\begin{array}{c}\text { Coklat } \\
\text { kekuning } \\
\text { an. }\end{array}$ & $\begin{array}{c}\text { Coklat } \\
\text { kekuning } \\
\text { an. }\end{array}$ \\
\hline
\end{tabular}

Keterangan: F1 volume santan kelapa $30 \mathrm{~mL}$ dan volume akhir $400 \mathrm{~mL}$.

Tabel 3.5 Hasil Pengamatan Kue Kapit Sari Lidah Buaya F3

\begin{tabular}{|c|c|c|c|c|c|c|c|c|c|c|}
\hline \multirow{2}{*}{$\begin{array}{c}\text { SAMP } \\
\text { EL }\end{array}$} & \multirow{2}{*}{$\begin{array}{c}\text { Uji } \\
\text { Organ } \\
\text { olepti } \\
\text { k }\end{array}$} & \multicolumn{3}{|c|}{ Minggu Ke-1 } & \multicolumn{3}{|c|}{ Minggu ke-2 } & \multicolumn{3}{|c|}{ Minggu ke-3 } \\
\hline & & $\mathrm{H}+1$ & $\mathrm{H}+3$ & $\mathrm{H}+6$ & $\mathrm{H}+1$ & $\mathrm{H}+3$ & $\mathrm{H}+6$ & $\mathrm{H}+1$ & $\mathrm{H}+3$ & $\mathrm{H}+6$ \\
\hline \multirow{6}{*}{$\begin{array}{c}\text { F } 1 \\
( \\
\text { Lima } \\
\text { belas } \\
\text { Kue } \\
\text { Kapit } \\
\text { J }\end{array}$} & $\mathrm{Bau}$ & $\begin{array}{l}\text { Berarom } \\
\text { a khas } \\
\text { telur }\end{array}$ & $\begin{array}{c}\text { Berarom } \\
\text { a khas } \\
\text { telur }\end{array}$ & $\begin{array}{c}\text { Berarom } \\
\text { a khas } \\
\text { telur }\end{array}$ & $\begin{array}{c}\text { Berarom } \\
\text { a khas } \\
\text { telur }\end{array}$ & $\begin{array}{c}\text { Berarom } \\
\text { a khas } \\
\text { telur }\end{array}$ & $\begin{array}{c}\text { Berarom } \\
\text { a khas } \\
\text { telur }\end{array}$ & $\begin{array}{c}\text { Berarom } \\
\text { a khas } \\
\text { telur }\end{array}$ & $\begin{array}{c}\text { Berarom } \\
\text { a khas } \\
\text { telur }\end{array}$ & $\begin{array}{c}\text { Berarom } \\
\text { a khas } \\
\text { telur }\end{array}$ \\
\hline & $\begin{array}{c}\text { Bentu } \\
\mathrm{k}\end{array}$ & $\begin{array}{l}\text { berbentu } \\
\text { k seperti } \\
\text { kipas } \\
\text { utuh dan } \\
\text { tidak } \\
\text { pecah- } \\
\text { pecah }\end{array}$ & $\begin{array}{l}\text { berbentu } \\
\text { k seperti } \\
\text { kipas } \\
\text { utuh dan } \\
\text { tidak } \\
\text { pecah- } \\
\text { pecah }\end{array}$ & $\begin{array}{l}\text { berbentu } \\
\text { k seperti } \\
\text { kipas } \\
\text { utuh dan } \\
\text { tidak } \\
\text { pecah- } \\
\text { pecah }\end{array}$ & $\begin{array}{l}\text { berbentu } \\
\text { k seperti } \\
\text { kipas } \\
\text { utuh dan } \\
\text { tidak } \\
\text { pecah- } \\
\text { pecah }\end{array}$ & $\begin{array}{l}\text { berbentu } \\
\text { k seperti } \\
\text { kipas } \\
\text { utuh dan } \\
\text { tidak } \\
\text { pecah- } \\
\text { pecah }\end{array}$ & $\begin{array}{l}\text { berbentu } \\
\text { k seperti } \\
\text { kipas } \\
\text { utuh dan } \\
\text { tidak } \\
\text { pecah- } \\
\text { pecah }\end{array}$ & $\begin{array}{l}\text { berbentu } \\
\text { k seperti } \\
\text { kipas } \\
\text { utuh dan } \\
\text { tidak } \\
\text { pecah- } \\
\text { pecah }\end{array}$ & $\begin{array}{l}\text { berbentu } \\
\text { k seperti } \\
\text { kipas } \\
\text { utuh dan } \\
\text { tidak } \\
\text { pecah- } \\
\text { pecah }\end{array}$ & $\begin{array}{c}\text { berbentu } \\
\text { k seperti } \\
\text { kipas } \\
\text { utuh dan } \\
\text { tidak } \\
\text { pecah- } \\
\text { pecah }\end{array}$ \\
\hline & Jamur & Tidak ada & Tidak ada & Tidak ada & Tidak ada & Tidak ada & Tidak ada & Tidak ada & Tidak ada & Tidak ada \\
\hline & Rasa & $\begin{array}{c}\text { Gurih } \\
\text { manis } \\
\text { seimbang }\end{array}$ & $\begin{array}{c}\text { Gurih } \\
\text { manis } \\
\text { seimbang }\end{array}$ & $\begin{array}{c}\text { Gurih } \\
\text { manis } \\
\text { seimbang }\end{array}$ & $\begin{array}{c}\text { Gurih } \\
\text { manis } \\
\text { seimbang }\end{array}$ & $\begin{array}{c}\text { Gurih } \\
\text { manis } \\
\text { seimbang }\end{array}$ & $\begin{array}{c}\text { Gurih } \\
\text { manis } \\
\text { seimbang }\end{array}$ & $\begin{array}{c}\text { Gurih } \\
\text { manis } \\
\text { seimbang }\end{array}$ & $\begin{array}{c}\text { Gurih } \\
\text { manis } \\
\text { seimbang }\end{array}$ & $\begin{array}{c}\text { Gurih } \\
\text { manis } \\
\text { seimbang }\end{array}$ \\
\hline & $\begin{array}{c}\text { Tekst } \\
\text { ur }\end{array}$ & $\begin{array}{c}\text { Kering, } \\
\text { renyah, } \\
\text { tidak } \\
\text { mudah } \\
\text { rapuh } \\
\end{array}$ & $\begin{array}{c}\text { Kering, } \\
\text { renyah, } \\
\text { tidak } \\
\text { mudah } \\
\text { rapuh } \\
\end{array}$ & $\begin{array}{c}\text { Kering, } \\
\text { renyah, } \\
\text { tidak } \\
\text { mudah } \\
\text { rapuh }\end{array}$ & $\begin{array}{c}\text { Kering, } \\
\text { renyah, } \\
\text { tidak } \\
\text { mudah } \\
\text { rapuh } \\
\end{array}$ & $\begin{array}{c}\text { Kering, } \\
\text { renyah, } \\
\text { tidak } \\
\text { mudah } \\
\text { rapuh } \\
\end{array}$ & $\begin{array}{c}\text { Kering, } \\
\text { renyah, } \\
\text { tidak } \\
\text { mudah } \\
\text { rapuh } \\
\end{array}$ & $\begin{array}{c}\text { Kering, } \\
\text { renyah, } \\
\text { tidak } \\
\text { mudah } \\
\text { rapuh } \\
\end{array}$ & $\begin{array}{c}\text { Kering, } \\
\text { renyah, } \\
\text { tidak } \\
\text { mudah } \\
\text { rapuh } \\
\end{array}$ & $\begin{array}{c}\text { Kering, } \\
\text { renyah, } \\
\text { tidak } \\
\text { mudah } \\
\text { rapuh } \\
\end{array}$ \\
\hline & $\begin{array}{c}\text { Warn } \\
\text { a }\end{array}$ & $\begin{array}{c}\text { Coklat } \\
\text { kekuning } \\
\text { an. }\end{array}$ & $\begin{array}{c}\text { Coklat } \\
\text { kekuning } \\
\text { an. }\end{array}$ & $\begin{array}{c}\text { Coklat } \\
\text { kekuning } \\
\text { an. }\end{array}$ & $\begin{array}{c}\text { Coklat } \\
\text { kekuning } \\
\text { an. }\end{array}$ & $\begin{array}{c}\text { Coklat } \\
\text { kekuning } \\
\text { an. }\end{array}$ & $\begin{array}{c}\text { Coklat } \\
\text { kekuning } \\
\text { an. }\end{array}$ & $\begin{array}{c}\text { Coklat } \\
\text { kekuning } \\
\text { an. }\end{array}$ & $\begin{array}{c}\text { Coklat } \\
\text { kekuning } \\
\text { an. }\end{array}$ & $\begin{array}{c}\text { Coklat } \\
\text { kekuning } \\
\text { an. }\end{array}$ \\
\hline
\end{tabular}

Keterangan: F1 volume santan kelapa $30 \mathrm{~mL}$ dan volume akhir $450 \mathrm{~mL}$.

Pembuatan adonan dengan mencampurkan tepung beras, tepung sagu, telur ras, gula pasir, garam, air santan kelapa, dan yang paling utama yakni sari 
daun lidah buaya (Aloe vera L.). Pada saat pembuatan diusahakan kue kapit jangan sampai gosong, karena akan merusak penampilan dan tidak terlihat menarik. Hasil kue kapit sari daun lidah buaya yang didapat yaitu dari ketiga variasi komposisi F1, F2, dan F3 yang didapat pada F1 adalah 14 kue yang dihasilkan dari jumlah bahan kue kapit $350 \mathrm{~mL}, \mathrm{~F} 2$ didapatkan 16 kue kapit sari daun lidah buaya yang dihasilkan dari jumlah bahan kue kapit $400 \mathrm{~mL}$, dan F3 didapatkan 18 kue kapit sari daun lidah buaya (Aloe vera L.).

Formulasi kue kapit yang telah dibuat menjadi tiga variasi komposisi F1, F2, dan F3, kemudian dipilih formula kue kapit sari daun lidah buaya yang paling mendekati kriteria kue kapit dan paling mudah dikonsumsi dan tampilannya yang menarik.

Hasil kue kapit pada formula F1, F2 dan F3 yaitu memberikan karakteristik yang hampir sama pada bentuk, bau, rasa dan warna, akan tetapi berbeda pada tekstur pada tingkat kerapuhan, uji kerapuhan kue kapit dengan cara diuji/ dipatahkan. Dari ketiga variasi formulasi didapatkan tingkat kerapuhan yang berturut-turut dari rapuh, sedang dan rendah yaitu F3 (mudah rapuh), F2 (agak mudah rapuh), dan F1 (tidak mudah rapuh).

Perbedaan tingkat kerapuhan ini ternyata berkolerasi dengan kandungan jumlah volume santan pada adonan kue kapit. Hasil ini menujukkan tingkat kerapuhan tersebut dapat diberikan analisa hasil, bahwa perbedaan jumlah volume santan kelapa adalah $30 \mathrm{~mL}, 80 \mathrm{~mL}$, dan 130 $\mathrm{mL}$ menjadi penyebab utama yang berpengaruh terhadap tingkat kerapuhan dengan argumentasi semakin banyak kandungan santan kelapa pada formula kue kapit maka semakin rapuh sediaan kue kapit tersebut ${ }^{[10] .}$

Dari ketiga variasi formula kue kapit sari daun lidah buaya (Aloe vera L.) yang berbeda berdasarkan uji kerapuhan yang paling mendekati kriteia pada bentuk seperti kipas utuh dan tidak pecah-pecah, berwarna coklat kekuningan, rasa gurih dan manis seimbang, bau beraroma harum khas telur, dan bertekstur kering, renyah. dan agak rapuh adalah F2 dengan volume santan kelapa $80 \mathrm{~mL}$ dan volume akhir adonan 400 $\mathrm{mL}$.

Pada hasil uji organoleptik kue kapit sari daun lidah buaya (Aloe vera) pada formula F1, F2 an F3 menunjukkan hasil yang relatif stabil pada bentuk, bau, rasa, warna, tekstur dan tidak ada tumbuhnya jamur pada penyimpanan selama tiga minggu. Hal ini dinyatakan bahwa formula kue kapit yang berbeda variasi komposisi tidak mempengaruhi ketahanan sediaan kue kapit sari daun lidah buaya.

\section{SIMPULAN}

Pembuatan adonan dengan mencampurkan tepung beras, tepung sagu, telur ras, gula pasir, garam, air santan kelapa, dan yang paling utama yakni sari daun lidah buaya (Aloe vera L.). Pada saat pembuatan diusahakan kue kapit jangan sampai gosong, karena akan merusak penampilan dan tidak terlihat menarik. Hasil kue kapit sari daun lidah buaya yang didapat yaitu dari ketiga variasi komposisi F1, F2, dan F3 yang didapat pada F1 adalah 14 kue yang dihasilkan dari jumlah bahan kue kapit 350 mL, F2 didapatkan 16 kue kapit sari daun lidah buaya yang dihasilkan dari jumlah bahan kue kapit $400 \mathrm{~mL}$, dan F3 didapatkan 18 kue kapit sari daun lidah buaya (Aloe vera L.).

Formulasi kue kapit yang telah dibuat menjadi tiga variasi komposisi F1, F2, dan F3, kemudian dipilih formula kue kapit sari daun lidah buaya yang paling mendekati kriteria kue kapit dan paling mudah dikonsumsi dan tampilannya yang menarik.

Hasil kue kapit pada formula F1, F2 dan F3 yaitu memberikan karakteristik yang hampir sama pada bentuk, bau, rasa dan warna, akan tetapi berbeda pada tekstur pada tingkat kerapuhan, uji kerapuhan kue kapit dengan cara diuji/ dipatahkan. Dari ketiga variasi formulasi didapatkan tingkat kerapuhan yang berturut-turut dari rapuh, sedang dan rendah yaitu F3 (mudah rapuh), F2 (agak mudah rapuh), dan F1 (tidak mudah rapuh).

Perbedaan tingkat kerapuhan ini ternyata berkolerasi dengan kandungan jumlah volume santan pada adonan kue 
kapit. Hasil ini menujukkan tingkat kerapuhan tersebut dapat diberikan analisa hasil, bahwa perbedaan jumlah volume santan kelapa adalah $30 \mathrm{~mL}, 80 \mathrm{~mL}$, dan $130 \mathrm{~mL}$ menjadi penyebab utama yang berpengaruh terhadap tingkat kerapuhan dengan argumentasi semakin banyak kandungan santan kelapa pada formula kue kapit maka semakin rapuh sediaan kue kapit tersebut [10].

Dari ketiga variasi formula kue kapit sari daun lidah buaya (Aloe vera L.) yang berbeda berdasarkan uji kerapuhan yang paling mendekati kriteia pada bentuk seperti kipas utuh dan tidak pecah-pecah, berwarna coklat kekuningan, rasa gurih dan manis seimbang, bau beraroma harum khas telur, dan bertekstur kering, renyah. dan agak rapuh adalah F2 dengan volume santan kelapa $80 \mathrm{~mL}$ dan volume akhir adonan $400 \mathrm{~mL}$.

Pada hasil uji organoleptik kue kapit sari daun lidah buaya (Aloe vera) pada formula F1, F2 an F3 menunjukkan hasil yang relatif stabil pada bentuk, bau, rasa, warna, tekstur dan tidak ada tumbuhnya jamur pada penyimpanan selama tiga minggu. Hal ini dinyatakan bahwa formula kue kapit yang berbeda variasi komposisi tidak mempengaruhi ketahanan sediaan kue kapit sari daun lidah buaya.

\section{DAFTAR PUSTAKA}

1. Siska, H. (2018). Gambaran Pola Makan Dalam Kejadian Gastritis Pada Remaja Di Smp Negeri 1 Sekayam Kabupaten Sanggau. Jurnal ProNers, 3(1).

2. Darwis, W. (2012). Tanaman Obat Yang Terdapat Di Kota Bengkulu Yang Berpotensi Sebagai Obat Penyakit Dan Gangguan Pada Sistem Pencernaan. Konservasi Hayati, 2012, 8. 1:1-15
3. Surjushe A, Vasani R, and Saple D G, (2008), Aloe Vera: A Short Review, Indian Journal of Dermatology, 53(4): pp. 163-166.

4. Eamlamnam, K, Patumraj S, Visedopas $\mathrm{N}$, Thong-Ngam D, (2006), Effects of Aloe veraand sucralfate on gastric microcirculatory changes, cytokine levels and gastric ulcer healing in rats, World J Gastroenterol, 12: pp. 2034-2039

5. Gopinathan, S, Rameela, N, (2014), Antiulcer activity of aloe vera juice and aloe vera and amla fruit combined juice in ethanol induced ulcerated rats, International Journal of Pharmacy and Pharmaceutical Sciences, Vol 6, Issue 6, pp. 190-197.

6. Utami, P., Puspaningtyas, D. E., \& Gz, S. (2013). The miracle of herbs. AgroMedia.

7. Jayadinata P.E., Andriani S., dan Ratnasari D. (2017) Pembuatan Simping Herbal dari Daun Beluntas (Plucea Indica (L) Less) untuk perawatan kesehatan. E-journal.stikesholistic.ac.id.

8. Hart, E., \& Bond, M. (2000). Using action research. Using evidence in health and social care. London: Sage, 86-107.

9. Sundari, T., dan Elfi Anis Saati. (2010). Pembuatan Es Krim Lidah Buaya (Aloe chinensis) dengan Penambahan Gelling Agents.

[Online]. ejournal.umm.ac.id/index.php/ bestari/article/view/123/127. Universitas Muhammadiyah Malang.

10. Satuhu, S. S., \& Sunarmani, D. (2004). Membuat Aneka Dodol Buah. Penebar 